\title{
TEN-YEAR SEED BANK AND VEGETATION DYNAMICS OF A TIDAL FRESHWATER MARSH ${ }^{1}$
}

\author{
Mary Allessio LeCK² AND Robert L. Simpson
}

\author{
Biology Department, Rider University, Lawrenceville, New Jersey 08648; and \\ Natural Sciences Department, University of Michigan, Dearborn, Michigan 48128
}

\begin{abstract}
A decade-long examination was made of recruitment and establishment in a tidal freshwater high marsh along the Delaware River. Over the $10 \mathrm{yr}$ of the study, seed bank, field seedlings, and vegetation showed variable patterns and significant year-to-year fluctuations. Patterns of each species were unique, perhaps the result of specific germination and/or establishment requirements and seedling morphology. For a given species there was little correlation among seed bank, seedling, and vegetation patterns, and germination success did not guarantee establishment. Species diversity showed significant year-to-year fluctuation, but there was no trend, and perennials did not change in importance during the 10-yr period. Because four annual species (Bidens laevis, Cuscuta gronovii, Impatiens capensis, and Polygonum arifolium) composed over $90 \%$ of the seed bank and field seedlings, and $58-89 \%(\bar{x}=70 \pm 4)$ of the cover, community dynamics were dependent on seedling recruitment. For a given species life history stages (seed bank, field seedlings, and vegetation) were not predictable over the temporal scale of a decade. It is predicted, however, that if hydrology remains unchanged, the same suite of species will persist. The importance of the parasite Cuscuta gronovii is noteworthy.
\end{abstract}

Our previous studies of the Hamilton Marshes, a Delaware River tidal freshwater wetland, emphasized that the vegetation at a given site reflects the seed bank at that site (Parker and Leck, 1985; Leck and Simpson, 1987). This is in large measure due to the importance of annual species, which comprise from 31 to $86 \%$ of the seed bank and the reduced numbers of graminoids (Leck, 1989). Similarities between seed bank composition and vegetation have also been observed in other wetlands, such as coastal marshes (Hopkins and Parker, 1984), lakeshores (Keddy and Reznicek, 1982), and inland marshes (van der Valk and Davis, 1978; Pederson, 1981). (See Leck, 1989 for additional examples and exceptions.)

We have also found that species diversity in this marsh varies with life history stage, although few studies have examined the seedling stage (Leck, 1989). When there is lack of similarity between floristic composition of the vegetation and the seed bank, it may be due to a variety of factors, including dominant species that produce few or no viable seeds (e.g., Acorus calamus; Leck and Simpson, 1987), lack of specific germination requirements (e.g., Agalinis paupercula, a hemiparasite; Keddy and Reznicek, 1982), small seedling size (e.g., Typha latifolia or Bidens laevis; Leck and Simpson, 1993), or germination time (perennials, for example, tend to germinate later than annuals; Leck, Simpson, and Parker, 1989).

Interpretations of relationships between soil seed banks and vegetation are often based on data obtained from 1 or possibly 2 yr (Leck, Simpson, and Parker, 1989) or in fewer studies several times during a single year (e.g., Sarukhán, 1974; Thompson and Grime, 1979; Schneider

\footnotetext{
Manuscript received 20 October 1993; revision accepted 17 May 1995.

The authors thank Christine Cimpko, Julie Chang, Mary Festa, Elizabeth Falkenstein, Mary Kildea, Charles F. Leck, Lorraine Schepis, V. Thomas Parker, Mark Tulaba, and Rachel Wassum; Rebecca Schneider and anonymous reviewers for many helpful suggestions for manuscript revision; and David Campbell, Douglas Deutschman, and especially Peter Morin for advice regarding statistics. The work was supported by a Rider University Faculty Grant-in-Aid.

2 Author for correspondence.
}

and Sharitz, 1986). To our knowledge there are no studies that have examined seed banks in one site for a decade, although the desirability of long-term studies is acknowledged (Franklin, 1989).

In this 10-yr study we focused on a small spatial scale in a single high marsh site. Our goals were: (1) to document changes in seed bank size and composition, (2) relate these changes to annual regeneration and community structure by comparing the seed bank data with yearly field germination and mature vegetation cover, and (3) examine the relative success of annual vs. perennial species in long-term regeneration and establishment of this high marsh plant community. Regarding the second goal, we addressed the following questions: Are there correlations among seed bank, field seedling, and either current year or previous year cover? Is there evidence for dependent relationships among species involving the three life history stages (e.g., does cover of species A affect the seed bank of that species or other species the next year)?

\section{STUDY SITE}

The Hamilton Marshes have been the site of several seed bank studies (Leck and Graveline, 1979; Parker and Leck, 1985; Leck and Simpson, 1987, 1994). The high marsh site for this study, one of the sites studied by Leck and Simpson (1987), was located $\approx 100 \mathrm{~m}$ from a small, $\approx 0.7 \mathrm{~m}$ deep, stream channel and $\approx 100 \mathrm{~m}$ from a forested island with no transitional ecotone. The site is flooded for $\approx 3 \mathrm{hr}$ during each tide cycle. Additional information about the wetland may be found in Simpson et al. (1983).

The dominants are four annuals (Bidens laevis, Cuscuta gronovii, Impatiens capensis, and Polygonum arifolium) and four perennials (Acorus calamus, Peltandra virginica, Sagittaria latifolia, and Scirpus fluviatilis). The annual Zizania aquatica var. aquatica also occurs within the study site; other perennials include Leersia oryzoides, which is frequent, and Typha latifolia, which occurs in a thin stand $\approx 75 \mathrm{~m}$ away. By 1991 a small stand of Phal- 
aris arundinacea was established within $10 \mathrm{~m}$ of the east end of the site.

\section{MATERIALS AND METHODS}

Soil samples were obtained each year from 1982 to 1991 and seedling and vegetation data each year except 1985. Samples and field data were obtained along $15-\mathrm{m}$ transects oriented on a north-south axis perpendicular to the stream channel. Each year the transect was located $\approx 1 \mathrm{~m}$ away from that of the previous year. Over the $10 \mathrm{yr}$ there was probable overlap of transects, but due to the unconsolidated nature of the substrate, there was no evidence of where samples had been removed. The chance of superimposing sample locations across all years was small. The site, which had been chosen for its uniform vegetation (Leck and Simpson, 1987), was $\approx 15 \mathrm{~m}$ wide.

Soil samples-Each year samples were collected during March before field germination had begun; dates ranged from 3 to 30 March. Ten $10 \times 10 \times 2$ (deep) $\mathrm{cm}$ samples were collected at $\approx 1-\mathrm{m}$ intervals using a serrated knife to prevent compaction. Each sample was placed into a plastic bag; in the greenhouse the sample was spread in a layer $\approx 1 \mathrm{~cm}$ thick on $2-3 \mathrm{~cm}$ of moistened perlite in a $20 \times 20 \times 4.5 \mathrm{~cm}$ aluminum pan. Samples received ambient photoperiod, $\approx 30 \%$ solar illuminance, and a temperature range of 5-30 C. Soils were kept saturated with distilled water and fertilized (5:5:5 N:P:K) twice during the growing season.

At weekly intervals seedlings that could be identified were removed. Samples were monitored regularly from March until the 1st wk in December. The numbers of seedlings emerging from these samples were used to estimate seed banks. A previous study (Leck and Simpson, 1987) determined that $1.9 \%$ ungerminated seeds remained to germinate during a second growing season. Therefore, germination was considered to be an adequate method of quantifying seeds in the seed bank.

Field vegetation-Seedling densities were estimated by counting seedlings at the approximate time of maximum density (Parker and Leck, 1985) on dates ranging from 22 April to 13 May. Fifteen $10 \times$ $10 \mathrm{~cm}$ quadrats located along the transect where soil samples were collected in March were examined.

Vegetation was determined from ten $50 \times 50 \mathrm{~cm}$ quadrats located along the soil sample transects on dates ranging from 27 June to 26 July. The original transect could not be relocated in 1991; vegetation was determined along a parallel transect $2-3 \mathrm{~m}$ away. Percent cover as well as species present in the quadrat but not contributing to cover were recorded as being present, because they too contribute to the seed bank. The presence data were used to determine species totals and frequency; only those species actually contributing to cover were used for vegetation analyses. The exception was that in regression analyses involving Cuscuta gronovii cover, presence was arbitrarily assigned the value of 1 .

Species area curves, often used to address sampling adequacy, show considerable variation from year to year for a life history stage; mean values (Fig. 1) indicate that the sampling design for each life history stage was, in fact, adequate. The size and number of seed bank samples, totaling $1,000 \mathrm{~cm}^{2}$, are within the range for terrestrial pastures (Forcella, 1984) and similar to that $\left(1,280 \mathrm{~cm}^{2}\right)$ for wetlands (Brock. Theodore, and O'Donnell, 1994). Although a large number of small samples may be preferable to fewer large ones (e.g., Bigwood and Inouye, 1988), potential seed or fruit sizes ranging from $<0.1 \mathrm{~mm}$ (e.g., Juncus effusus) to $>1 \mathrm{~cm}$ (e.g., Peltandra virginica) influenced our sampling design. It seemed that small samples would not adequately census Peltandra virginica fruits.

Nomenclature follows Fernald (1970) except Zizania aquatica var. aquatica L. (Gleason, 1952) and Phragmites australis (Gleason and Cronquist, 1991).

Some data for 1982 and 1983 were previously reported in Leck and Simpson (1987) and for 1982-1985 in Leck, Simpson, and Parker (1989).

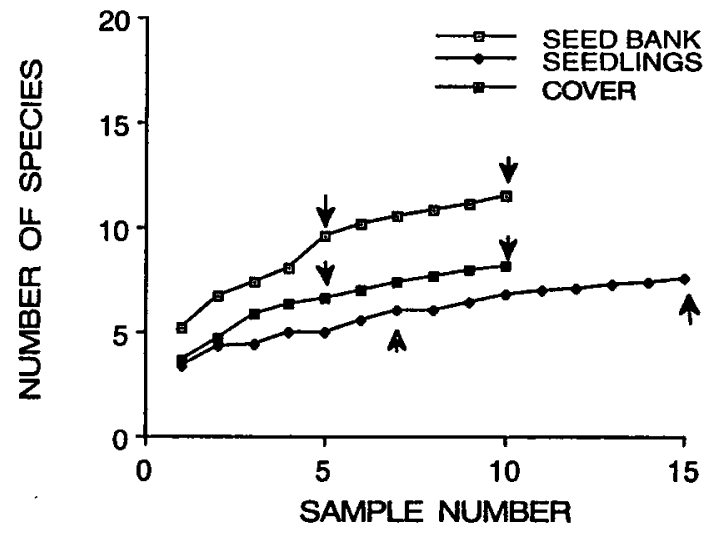

Fig. 1. Species area curves for seed bank, field seedlings, and vegetation (cover). Values are means over $10 \mathrm{yr}(N=10$ soil samples for seed bank; $N=9$ quadrats for field seedlings and cover). Arrows indicate range of samples that are statistically similar $(P \leq 0.05)$ based on Duncan's multiple range test.

Statistical analysis - to determine changes in life history stages and relationships among stages a number of analyses were used. These included:

Density and diversity-Density data are presented as $\bar{x} \pm \mathrm{SE}$ seedlings $/ \mathrm{m}^{2}$ and richness as species/sample or total species.

Variability-For individual species' densities and totals, the $95 \%$ confidence limit $(\bar{x} \pm L ; L=1.96 \mathrm{~s} / \sqrt{n} ;$ Zar, 1979) was used to test differences and establish variability from $10-y r$ means. For a comparison of the variability among life history stages, coefficients of variation, which allow comparisons between data having different units (e.g., no. $/ \mathrm{m}^{2}$ and \% cover), are reported.

Changes over time-The repeated-measures analysis of variance (RMANOVA) was used to determine whether seed bank, field seedlings, and vegetation (cover) changed over time and whether there was a year $\times$ category effect (i.e., whether the variation over time depended on the species or category examined). The three categories were: (a) dominants, including Bidens laevis, Cuscuta gronovii, Impatiens capensis, Peltandra virginica, and Polygonum arifolium; (b) number of species, including species/sample and perennial species/sample; and (c) total densities, including annuals and perennials. For the RMANOVA Wilks' lambda values are reported. We used analysis of variance (ANOVA) to help interpret the RMANOVA. The ANOVA, coupled with Duncan's multiple range test, allowed us to determine any trends over time of individual species, species/sample, perennials/sample, or totals.

Relationships among life history stages-Correlation analysis was used to establish relationships among seed bank and field seedlings, and the vegetation of the preceding year or the current year. Spearman correlation coefficients were examined.

Dependent relationships - Simple linear regressions were used to determine dependent (predictable) relationships. Three questions were examined in an attempt to identify relationships between dominant species, life history stages, and annuals and perennials. These were: (1) Within a life history stage are there dependent relationships among species (i.e., does high seed bank density of species A affect that of species B)? (2) Is the current year cover dependent on seed bank or field seedling values? (3) Are there intra- or interspecies dependent relationships between last season's cover and the current year's seed banks or field seedlings? Seed bank data were also transformed $\left(Y^{\prime}=\sqrt{y+0.5}\right.$ for count data; Zar, 1979), but examination of results indicated that trans- 
TABLE 1. Frequency (FQ) and $\%$ of total $(\bar{X} \pm \mathrm{SE}$ ) over $10 \mathrm{yr}$ for species exceeding $5 \%$ for one or more stages. (For frequency each year $N=$ 10 soil samples for seed bank, 15 quadrats for field seedlings, and ten quadrats for vegetation. Percent of total is based on yearly values; seed bank $N=10 \mathrm{yr}$, and field seedlings and $\operatorname{cover} N=9 \mathrm{yr}$.)

\begin{tabular}{|c|c|c|c|c|c|c|}
\hline & \multicolumn{2}{|c|}{ Seed bank } & \multicolumn{2}{|c|}{ Field seedlings } & \multicolumn{2}{|c|}{ Vegetation } \\
\hline & $\overline{F Q}$ & $\%$ & $\mathrm{FQ}$ & $\%$ & $\mathrm{FQ}$ & $\%$ \\
\hline Acorus calamus $(\mathrm{P})^{\mathrm{a}}$ & 0 & 0 & 0 & 0 & $59 \pm 8$ & $3.9 \pm 1.0$ \\
\hline Bidens laevis (A) & $72 \pm 9$ & $12 \pm 4$ & $51 \pm 12$ & $19.3 \pm 8.4$ & $40 \pm 13$ & $4.2 \pm 1.7$ \\
\hline Impatiens capensis (A) & $92 \pm 4$ & $14 \pm 1$ & $84 \pm 7$ & $20.5 \pm 4.5$ & $96 \pm 3$ & $28.8 \pm 4.7$ \\
\hline Leersia oryzoides $(\mathrm{P})$ & $10 \pm 1$ & $<1$ & $5 \pm 3$ & 0 & $30 \pm 7$ & $0.7 \pm 0.4$ \\
\hline Peltandra virginica $(\mathrm{P})$ & $30 \pm 4$ & $2 \pm 1$ & $21 \pm 4$ & $1.9 \pm 0.5$ & $76 \pm 8$ & $19.2 \pm 2.8$ \\
\hline Phragmites australis $(\mathrm{P})$ & $7 \pm 3$ & $<1$ & 0 & 0 & 0 & 0 \\
\hline Sagittaria latifolia $(\mathrm{P})$ & $5 \pm 2$ & $<1$ & $1 \pm 1$ & $<1$ & $56 \pm 9$ & $4.5 \pm 1.5$ \\
\hline Scirpus fluviatilis (P) & 0 & 0 & 0 & 0 & $56 \pm 12$ & $3.7 \pm 1.1$ \\
\hline Typha latifolia $(\mathrm{P})$ & $26 \pm 5$ & $1 \pm 1$ & $1 \pm 1$ & $<1$ & 0 & 0 \\
\hline Zizania aquatica var. aquatica (A) & $4 \pm 3$ & 0 & $5 \pm 2$ & $<1$ & $19 \pm 5$ & $0.9 \pm 0.3$ \\
\hline
\end{tabular}

${ }^{\text {a }} \mathrm{P}=$ perennial, $\mathrm{A}=$ annual.

formation was not necessary (P. Morin, personal communication, Rutgers University).

For regression analysis, all combinations of species, as well as annuals, perennials, and totals (except cover) were used as dependent and independent variables. Plots of all significant relationships were examined.

\section{COVER}

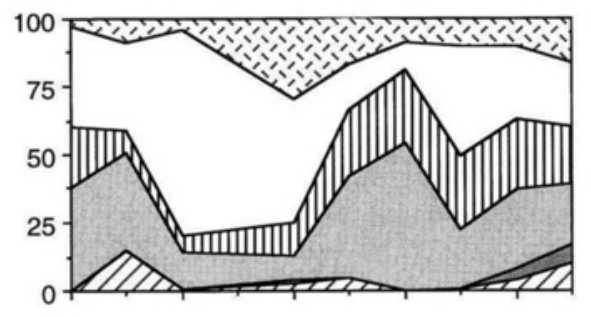

FIELD SEEDLINGS
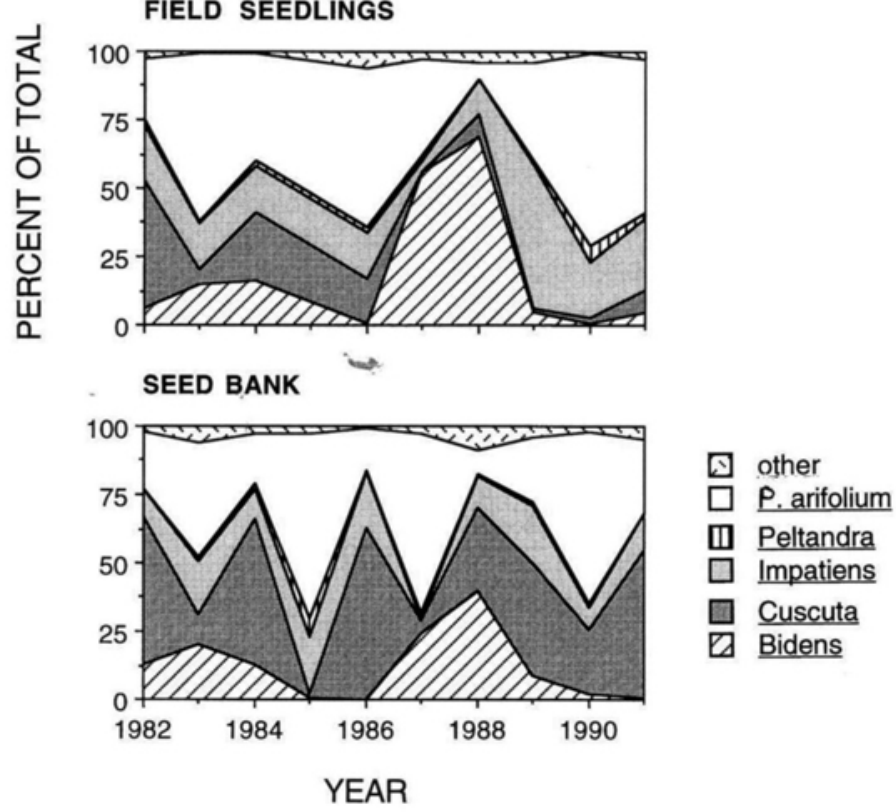

Fig. 2. Contribution to seed bank, field seedlings, and cover (\% of total) of Bidens laevis, Cuscuta gronovii, Impatiens capensis, Peltandra virginica, Polygonum arifolium, and other species. Note that no field seedling or cover data were obtained in 1985.
Except for the $95 \%$ confidence limit used to test differences from 10 yr means, analyses used SAS (1989) procedures.

\section{RESULTS}

Importance, density, and diversity - The five dominant species, four annuals, Bidens laevis, Cuscuta gronovii, Impatiens capensis, and Polygonum arifolium, and one perennial, Peltandra virginica, consistently had high frequency and/or represented a large component of each life history stage (Table 1). These species were considered to be the most important to vegetation dynamics and are the focus of the analyses presented below.

Seed bank, field seedlings, and vegetation will be considered in turn. Four annual species (Bidens laevis, Cuscuta gronovii, Impatiens capensis, and Polygonum arifolium) (Figs. 2, 3), comprised 91-98\% of the total seed bank. Densities of annuals showed considerable variation from year to year (Figs. 2, 3; Table 2). The seed bank of Bidens laevis, for example, was 0 in 1986 and 1,950 \pm $873 / \mathrm{m}^{2}$ in 1987 , Cuscuta gronovii $4,470 \pm 1,058$ in 1984 and $50 \pm 50$ in 1985, and Polygonum arifolium 5,390 \pm 614 in 1987 and $450 \pm 79$ in 1988 . However, the differences from the 10-yr mean (Fig. 3) for the dominants show no common pattern. The apparent exception was that seed bank totals, showing year-to-year oscillation around the 10-yr mean, generally reflect the trends seen in Cuscuta gronovii.

Seed bank richness ranged from $3.4 \pm 0.4$ to $6.6 \pm$ 0.6 species/sample and 8 to 15 total species each year $(\bar{x}$ $=11.3 \pm 0.9$ ) (Table 2). Over the $10 \mathrm{yr}, 33$ species germinated in soil samples (Appendix 1). Of these, 11 were not found in the immediate vicinity of the site (Andropogon virginicus, Conyza canadensis, Cyperus sp., Epilobium coloratum, Erechtites hieracifolia, Gnaphalium obtusifolium, Mikania scandens, Panicum dichotomiflorum, Paulownia tomentosa, Phragmites australis, and Solidago sp.); except for Panicum dichotomiflorum and Cyperus sp., all are wind dispersed.

Field seedling densities, with a high of 4,607 \pm 540 seedlings $/ \mathrm{m}^{2}$ in 1988 and low of $707 \pm 73$ seedlings in 1986, like those of the seed bank, showed considerable variation among years (Table 2). Richness was between $2.4 \pm 0.2$ and $4.2 \pm 0.2$ species/sample and between 5 
BIDENS
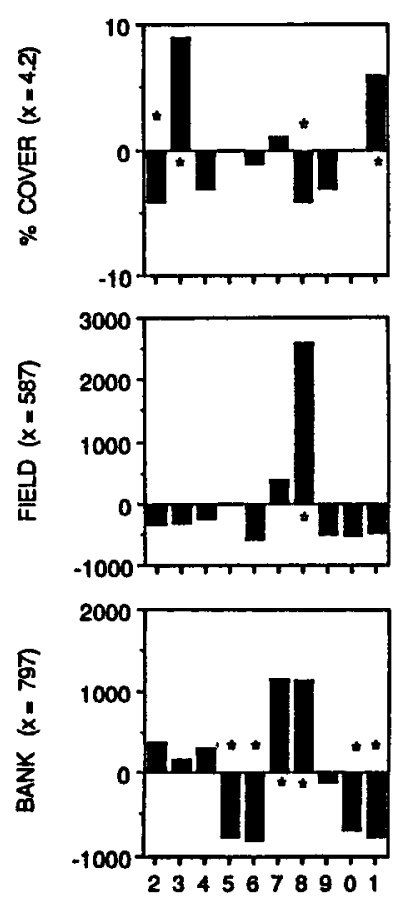

YEAR
Cuscuta
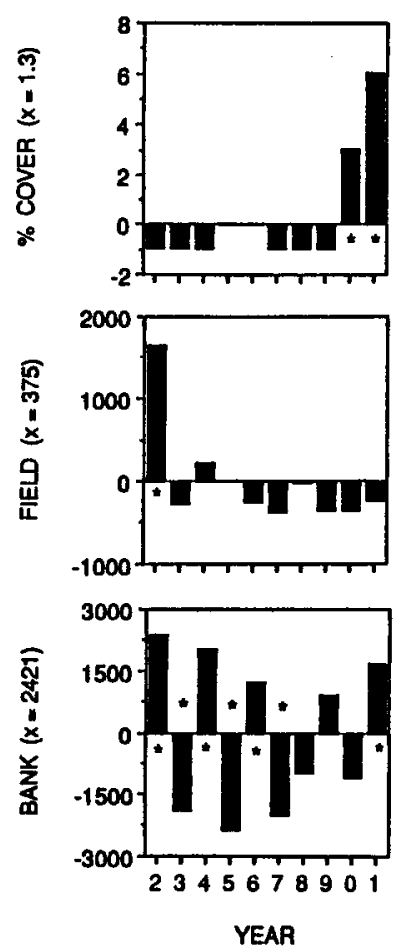

P. ARIFOLIUM
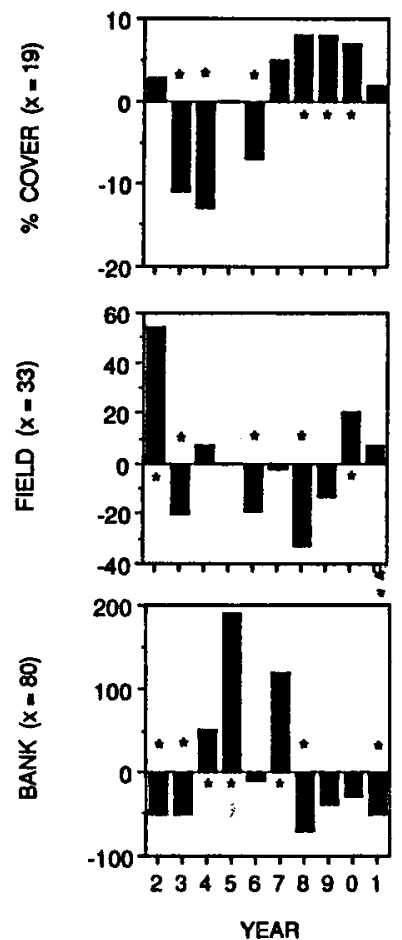
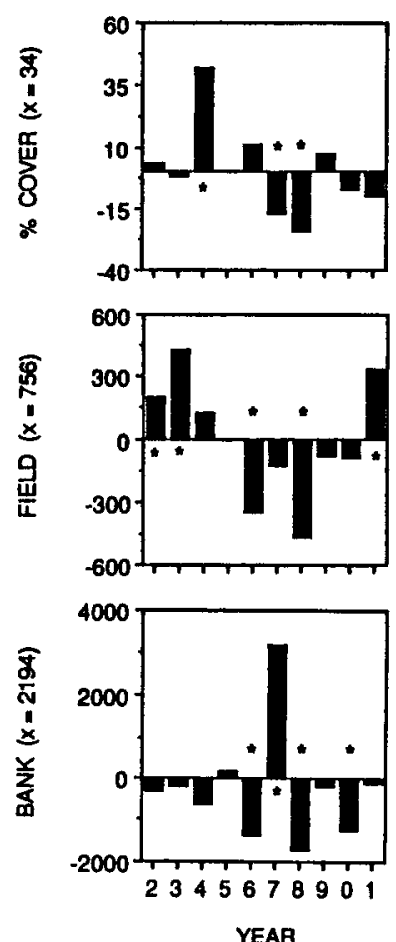

IMPATIENS
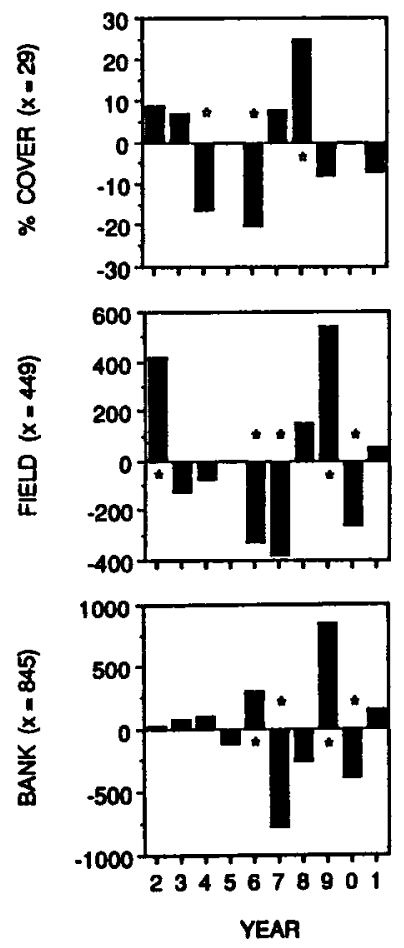

TOTAL
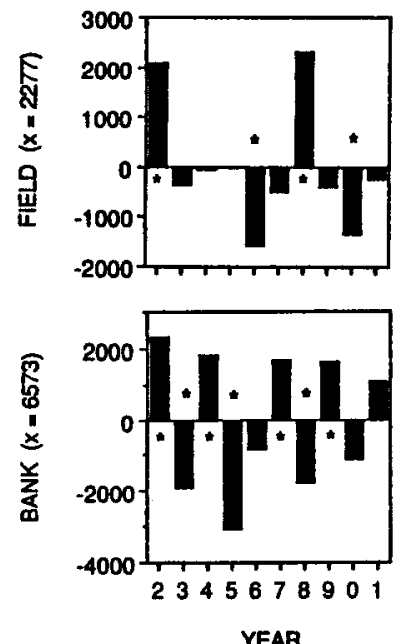

Fig. 3. Yearly differences from the 10-yr mean of Bidens laevis, Cuscuta gronovii, Impatiens capensis, Polygonum arifolium, Peltandra virginica, and total for seed bank, field seedlings, and cover; 10 -yr means are given in parentheses on the $y$-axes. The $\star$ indicates that the value exceeds the 95\% confidence limit. The year numbers are the last digit of any given year (i.e., $2=1982$ ). 
and $11(\bar{x}=7.3 \pm 0.7$ species $) / y r$ (Table 2$)$. Thirteen species were recorded in field seedling quadrats. The same four annuals (Bidens laevis, Cuscuta gronovii, Impatiens capensis, and Polygonum arifolium) that dominated the seed bank comprised $90-98 \%$ of the seedlings observed. The only common perennial species was Peltandra virginica; others, Leersia oryzoides, Sagittaria latifolia, Sium suave, and Typha latifolia, were uncommon $(n=12)$. Total field seedling values (Table 2; Fig. 3) were $12-95 \%(\bar{x}$ $=34 \pm 9 \%$ ) of the seed bank values. For the common species field seedling densities were usually considerably less than seed bank values. Exceptions were Bidens laevis in 1988 and 1991, Impatiens capensis in 1988, and Peltandra virginica in 1982, 1990, and 1991 (Table 3).

Species richness of the vegetative cover ranged from $3.0 \pm 0.3$ to $6.0 \pm 0.4 \mathrm{species} / \mathrm{sample}$ and from 6 to 10 total species/yr (Table 2). Twelve species contributed to cover; three others (Polygonum sagittatum, Fraxinus sp., and Pilea pumila) were also present. Of these three additional species, only Pilea pumila contributed to the seed bank. Together Polygonum arifolium and Impatiens capensis contributed $>60 \%$ to cover. Low cover values for Cuscuta gronovii, it should be noted, are related to the time of sampling; this species becomes more conspicuous as the season progresses.

The perennials, Acorus calamus, Peltandra virginica, Sagittaria latifolia, and Scirpus fluviatilis, were frequent and contributed to cover, with Peltandra virginica being the most important (Table 1). Neither Acorus calamus nor Scirpus fluviatilis were found as seedlings. Peltandra virginica represented $1 \%$ of the seed bank and $1.6 \%$ of field seedling densities. There were few Sagittaria latifolia seedlings in seed bank samples $(\ll 1 \%)$ probably due to the fact that samples were not continuously flooded (Leck and Simpson, 1987) and only one was recorded in the field.

Woody/shrubby species were uncommon. Single seedlings of Hibiscus palustris, Cephalanthus occidentalis, and Paulownia tomentosa germinated in the soil samples and one of Fraxinus sp. was found when determining cover.

Ten-year variability-Seed bank and field seedling densities and cover of Bidens laevis, Cuscuta gronovii, Impatiens capensis, Peltandra virginica, Polygonum arifolium, as well as seed bank and field seedling totals, showed significant variability from the 10 -yr mean (Fig. 3). Coefficients of variation (Table 4) showed that Impatiens capensis, Polygonum arifolium, total densities, annuals, and total species/sample had low values, generally $<100$, with similar values across life history stages.

Year and category $\times$ year effects-For seed bank and field seedlings RMANOVA showed significant differences over time in the three categories examined, dominants, species/sample, and totals (Table 5). Vegetation (cover) for the dominants and totals showed no differences over time while cover for species showed no year $X$ species interaction. ANOVA and Duncan's multiple range test results showed no consistent year rankings for life history stages. For example, Bidens laevis high field seedling values for 1988 and 1987 were significantly different from each other and from all other years $(P$
$<0.001$ ), but cover values were low; for Polygonum arifolium 1987 and 1990 seed bank values were significantly greater than those of other years $(P<0.001)$, but field seedling and cover values for those years were low. Peltandra virginica and total perennials did not differ significantly over $10 \mathrm{yr}$ for any life history stage.

Relationships between life history stages-For the five dominant species, perennial species/sample, perennials, and totals over the $10 \mathrm{yr}$, there were few significant correlations between seed bank $\times$ field seedlings, seed bank $x$ cover, and field seedlings $\times$ cover for a given year, or for previous year cover $x$ seed bank, and previous year cover $X$ field seedlings. In fact, there were fewer significant values $(8)$ than possible by chance $(18 ; 0.05 \times 369)$. These results suggest that for a species high cover values in a given year were not related to high seed bank or high field seedling values the next year, nor were cover values correlated with seed bank or field seedling values of that year.

Dependent relationships-Regression analyses were designed to answer the following questions: (a) are there dependent relationships among species within a life history stage, (b) are seed bank and seedling densities influenced by the vegetation (cover) of the previous year, and (c) is vegetation dependent on current year seed bank and field seedling densities? Analyses within life history stages (Table 6A) showed a number of dependent relationships, notably among Impatiens capensis, Polygonum arifolium, and Cuscuta gronovii. Slopes were generally positive for seed bank and field seedling comparisons, but negative for cover, which means that higher seed bank densities were correlated with higher seedling densities but not with cover. However, a particular relationship did not hold across all three life history stages. For example, low Impatiens capensis was related to high Polygonum arifolium in seed bank and cover stages, but not for seedlings, and Bidens laevis appeared to be negatively influenced by Polygonum arifolium in the field seedling stage, but not in seed bank or cover stages. Bidens laevis seed bank values varied independently of other dominants; only its seedling values depended on Polygonum arifolium (Table 6). The dependence of the total seed bank on Cuscuta gronovii seed bank was strongly positive, as was the dependence of the total field seedling density on Cuscuta gronovii field seedling density (see also Fig. 2).

Current year cover was largely independent of seed bank and field seedlings (Table 6B). Both Impatiens capensis and Polygonum arifolium cover appeared negatively influenced by Bidens laevis field seedling densities. Interestingly, high Impatiens capensis cover appears to have been negatively related to its high seed bank densities. These results indicate that high seed bank or field seedling densities did not result in increased cover for any of the dominant species. Because of the low $r^{2}$ values of many regressions, any predictions would be tenuous.

The dependence between annual cover and perennial cover, as expected, was highly significant.

Analysis of seed bank and field seedling densities with previous year cover (Table 6C), also showed a number of significant relationships among Cuscuta gronovii, Impatiens capensis, and Polygonum arifolium. None of 
TABI.F: 2. Ten-year summary for seed bank, field seedlings, and vegetation. Except for total species and cover species, values are $\bar{X} \pm$ SE:

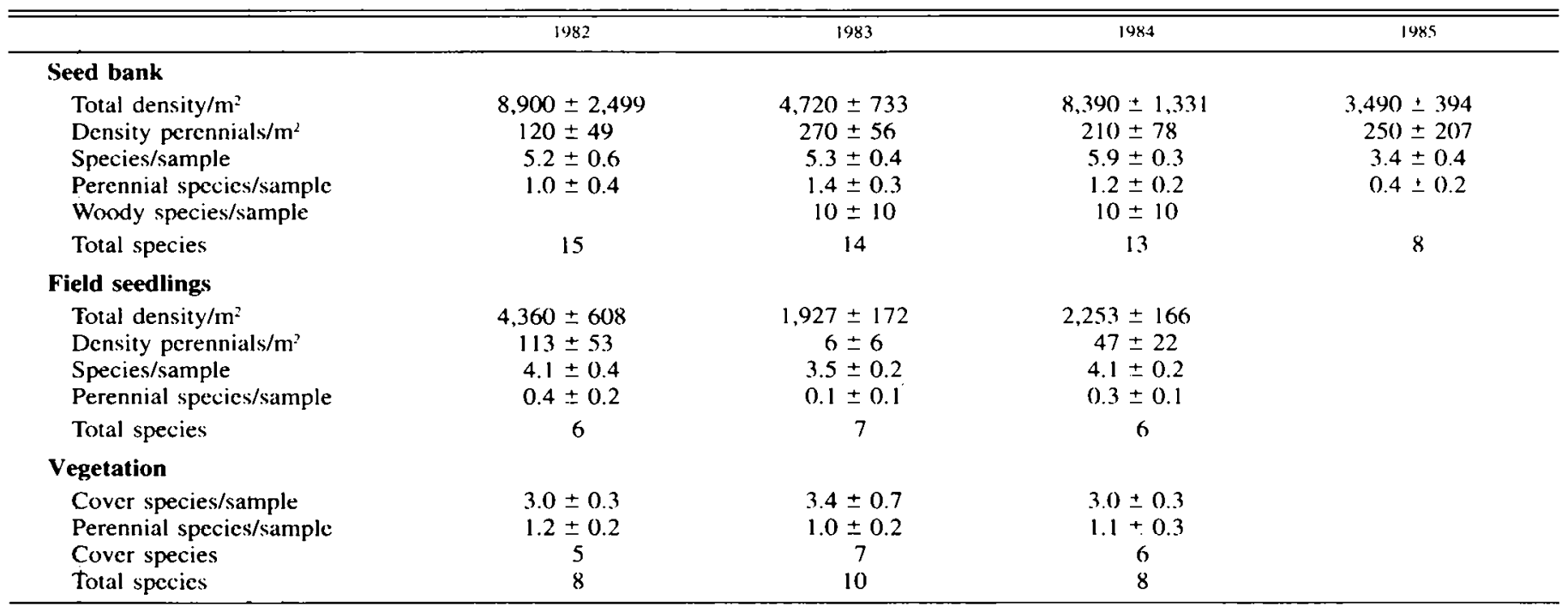

these interactions occurred across the three life history stages. A seemingly incongruous relationship occurred between Bidens laevis cover and Cuscuta gronovii because Bidens laevis occurred in few other significant relationships. However, this may reflect the dependent cover relationship of Bidens laevis with Impatiens capensis and Polygonum arifolium (Imp + Poly; Table 6A). The number of dependent relationships decreased from secd bank to field seedling to cover.

\section{DISCUSSION}

This long-term study showed that (1) there is considerable year-to-year variability in seed bank and field seedling densities and vegetation (percent cover) for each species; (2) regression analysis showed a number of dependent relationships between seed bank, field seedling, and vegetation of either the previous year or current year, but because of low $r^{2}$ values, these relationships were not strong, and thus (3) species appeared to vary independently of one another over time; and (4) annuals are a significant and continuing force in community dynamics as are perennials despite the paucity of the latter in the seed bank or field seedling stages. In this discussion we consider the importance of the time scale to vegetation dynamics, the community perspective, and specific species' strategies.
Temporal scales-In our early studies, based only on 1 or $2 \mathrm{yr}$, we reported that the seed bank reflects the vegetation at a given site (Leck and Graveline, 1979; Parker and Leck, 1985; Leck and Simpson, 1987; Leck, Simpson, and Parker, 1989). This is true on one spatial scale; Polygonum punctatum and Acnida (Amaranthus) cannabina were common in stream channel sites and $T y$ pha latifolia dominated a cattail site. However, by examining a community for a decade, it becomes obvious from this study that the dominants fluctuate relative to one another. Over longer periods of time, several decades, centuries, or millennia, others have shown that dominant species change in this wetland (or wetlands of similar type) (Orson, Simpson, and Good, 1992). Most likely, the dynamics of the time scale phenomenon involve differing factors that drive the change. Spatial differences observed over a short period (1-2 yr) may involve varying tolerances to physical (c.g., driven by hydrology) or biotic stresses (Parker and Leck, 1985). Over a decade (at one site) hydrological factors may be less important, but biotic influences (competition, but also predation and parasitism) as well as particular species' responses to microhabitat and chance may determine the recruitment and establishment patterns seen in this study. On a longer scale, during the centuries following colonization by Europeans, human impact has been substantial (Orson, Simpson, and Good, 1992).

TABI.E 3. Relationship of field seedling to seed bank densities (seedling/seed bank ratio) of common high marsh species and total.

\begin{tabular}{|c|c|c|c|c|c|c|c|c|c|}
\hline \multirow[b]{2}{*}{ Species } & \multicolumn{9}{|c|}{ Year } \\
\hline & 1982 & 1983 & 1984 & 1986 & 1987 & 1988 & 1989 & $19(x)$ & 1991 \\
\hline Bidens laevis & 0.22 & 0.29 & 0.32 & $\mathbf{a}$ & 0.50 & 1.65 & 0.15 & 0.11 & 2.67 \\
\hline Cuscuta gronovii & 0.42 & 0.19 & 0.13 & 0.03 & 0.00 & 0.25 & 0.004 & 0.02 & 0.04 \\
\hline Impatiens capensis & 0.99 & 0.35 & 0.40 & 0.11 & 0.86 & 1.03 & 0.58 & 0.41 & 0.50 \\
\hline Peltandra virginica & 2.90 & 0.43 & 0.31 & 0.47 & 0.16 & 0.00 & 0.50 & 1.06 & 1.33 \\
\hline Polygonum arifolium & 0.52 & 0.60 & 0.57 & 0.48 & 0.12 & 0.65 & 0.34 & 0.20 & 0.53 \\
\hline Total & 0.49 & 0.41 & 0.27 & 0.12 & 0.21 & 1.06 & 0.23 & 0.17 & 0.27 \\
\hline
\end{tabular}

Seed bank $=0$ 
TABle 2. Extended.

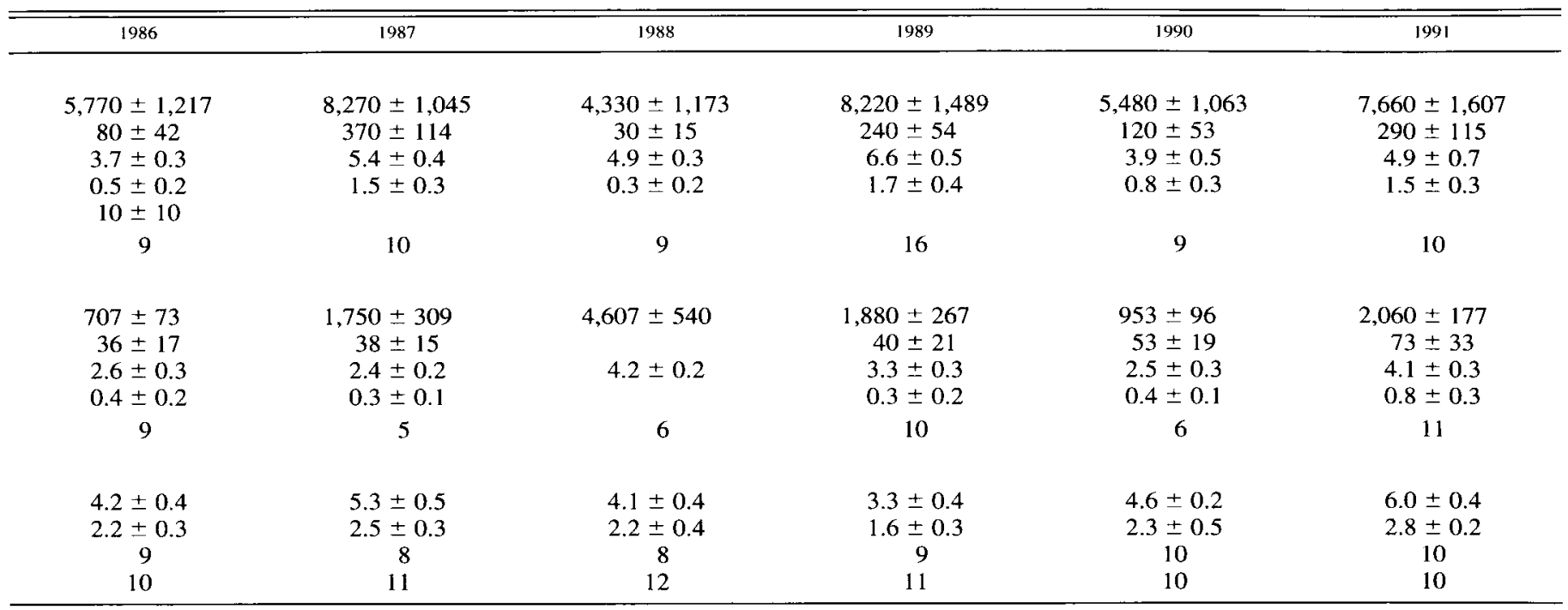

Community perspective-At the community level there were three noteworthy features: lack of predictability for a given species, continuing dominance by annuals, and persistence of perennials despite the dominance of annuals in the seed bank and field seedling stages. Lack of predictability is indicated by inconsistent regression relationships among life history stages and low $r^{2}$ values (Table 6). Over the decade there was considerable variability among years and among species (Fig. 3; Table 4). Moreover, results from RMANOVA (Table 5), the variable correlation coefficients (Table 4), and correlation analysis also support the conclusion that the importance of life history stages for a given species varies (Figs. 2, 3 ), and the dependent relationships among species and between life history stages are not strong (Tables 4-6). Germination success did not guarantee establishment. In years with large seed banks (e.g., Bidens laevis 1987 and 1988, Cuscuta gronovii 1984, and Polygonum arifolium 1987), there was poor establishment (low cover) (Fig. 2). However, the site does not experience drought, soil is uniform, and nutrient distribution is probably uniform, therefore differential success must be related to biotic stresses and/or microsite differences in, and tolerances to, standing water during low tide. Factors contributing to establishment are poorly understood. Success is deter-

TABle 4. Coefficients of variation over $10 \mathrm{yr}$ for dominant species, totals, and no. species/sample.

\begin{tabular}{lrcc}
\hline \hline & $\begin{array}{c}\text { Seed } \\
\text { bank }\end{array}$ & $\begin{array}{c}\text { Field } \\
\text { seedlings }\end{array}$ & Cover \\
\hline Bidens laevis & 180 & 213 & 292 \\
Cuscuta gronovii & 171 & 228 & 430 \\
Impatiens capensis & 83 & 108 & 74 \\
Peltandra virginica & 323 & 259 & 123 \\
Polygonum arifolium & 78 & 77 & 77 \\
Total & 68 & 77 & - \\
Annuals & 70 & 78 & 34 \\
Perennials & 151 & 222 & 88 \\
Total species/sample & 33 & 35 & 35 \\
Perennial species/sample & 187 & 179 & 55 \\
\hline
\end{tabular}

mined by various factors, including litter deposition and decomposition patterns, predation, timing of storms during the spring, or conditions, including temperatures, timing of the tide cycle, and/or mud coating of seeds during seed afterripening and germination periods (Leck, Simpson, and Parker, 1989).

Often the proportion of seeds surviving to be seedlings in the field was considerably less than unity, indicating considerable losses (Table 3). This was especially obvious for Cuscuta gronovii, but varied with year for other species. However, we have little evidence of the importance of seed predation during and after seed production.

A second feature of this plant community is the importance of annuals (Table 1; Figs. 2, 3). Annual species make up $>90 \%$ of the seed bank and field seedlings and $70 \%(\bar{x}=70 \pm 4$; range $58-89 \%)$ of the vegetation. Accordingly, community dynamics are dependent on seedling recruitment. Somewhat earlier germination time of annuals (Leck, Simpson, and Parker, 1989) combined with large seedling size (especially of Impatiens capensis and Polygonum arifolium; Leck and Simpson, 1993) and high seed bank densities collectively control vegetation dynamics. This impact occurs regardless of which species are dominant in a given year.

Despite the importance of annuals in the seed bank and as field seedlings, perennials, especially Peltandra virginica, but also Acorus calamus, Sagittaria latifolia, and Scirpus fluviatilis, remained a consistent feature of the vegetation cover (Fig. 3). The continuing importance of perennials compared to annuals results from their longevity and the phenologically different productivity patterns (Whigham and Simpson, 1992).

Considerable variation existed in the vegetation as well as in population densities and species diversity of seed and seedlings, but there was no evidence (i.e., greater importance of perennials or woody species) for directional change (succession), supporting the conclusion of Mitsch and Gosselink (1986) that linear succession does not occur in aquatic ecosystems. Moreover, examination of aerial photographs from 1930 to 1980 showed similar 
TABLE 5. Wilks' lambda values for repeated-measures analysis of variance. Analysis categories were: (A) dominants-Bidens laevis, Cuscuta gronovii, Impatiens capensis, Polygonum arifolium, and Peltandra virginica; (B) no. species/sample and perennials/sample; and (C) annual total and perennial total. (NS $=P \geq 0.05$ ).

\begin{tabular}{|c|c|c|c|c|c|c|}
\hline \multirow[b]{2}{*}{ Life history stage } & \multicolumn{2}{|c|}{ A } & \multicolumn{2}{|c|}{ B } & \multicolumn{2}{|c|}{$\mathrm{C}$} \\
\hline & Year & Year $\times$ Dominants & Year & Year $\times$ Species & Year & Year $\times$ Total \\
\hline Seed bank & 0.0020 & 0.0001 & 0.0001 & 0.0095 & 0.0001 & 0.0001 \\
\hline Field seedlings & 0.0001 & 0.0001 & 0.0004 & 0.0001 & 0.0001 & 0.0001 \\
\hline
\end{tabular}

vegetation features to current ones. Perennials in addition to Peltandra virginica are frequent in seed bank and/or vegetation stages, but not as field seedlings (Fig. 2; Table 1 ), an observation noted elsewhere (Parker and Leck, 1985; Leck, Simpson, and Parker, 1989).

Species strategies-Individual species strategies differ. Some, for example, have transient seed banks, while others depend on persistent seed banks (Leck and Simpson, 1993, 1994). In addition, seedling phenology and size were observed to vary (see also Leck, Simpson, and Parker, 1989; Leck and Simpson, 1993); these attributes may ultimately contribute to the dynamics observed in this study (Figs. 2, 3). Moreover, as previously noted, biomass phenology of annuals and perennials differs (Whigham and Simpson, 1992).

Of the dominant species, Bidens laevis appears to have the greatest population swings, with some years favoring field germination (e.g., 1987 and 1988) yet not establishment. Year-to-year fluctuations have been observed at other sites, such as along the stream channel (Leck, Simpson, and Parker, 1989), and thus the high marsh is not an atypical site. The behavior of Bidens laevis, compared to the other dominant annuals, suggests that it has more specific germination and/or establishment requirements. Interestingly, of the annual dominants, it had the fewest dependent relationships (Table 6). This may indicate that it has the least impact on community dynamics and/or its population was not adequately assessed.

Germination studies (Leck, Baskin, and Baskin, 1994) show that Bidens laevis requires light, adequate aeration, and alternating temperatures following a long period of stratification at $5 \mathrm{C}$. Field and greenhouse germination appeared to be quite synchronous with those of Impatiens capensis and Polygonum arifolium. (In fact, in the greenhouse Bidens laevis germinated more quickly, e.g., $61 \%$ of the total in the 1 st wk compared with 7 and $15 \%$ in the other two species; V. T. Parker and M. A. Leck, unpublished data.) Thus, competitive success appears not to be related to relative emergence time (see Silander and Pacala, 1990). However, low cover values but fairly high frequency (Figs. 2, 3; Table 1) suggests that Bidens laevis seedlings are at a disadvantage. They are, in fact, smaller than Impatiens capensis and Polygonum arifolium at the time of germination (Leck and Simpson, 1993). Harper (1977) notes that small differences in height can have considerable effect on plant growth. It is possible that Bidens laevis seedlings, which may be shade tolerant, persist below the Impatiens-Polygonum seedling canopy until these weak-stemmed species topple over in midsummer, providing gaps.

Several authors (e.g., Harper, 1977; Grime, 1979; Til- man, 1988) emphasize the importance of plant morphology in population and community dynamics. The weakstemmed annuals Impatiens capensis and Polygonum arifolium grow so densely that they support one another; eventually they may grow too tall and topple over, surviving nicely as "semi" vines and often rooting at nodes. Thus, we postulate that if Bidens laevis seedlings, with an upright morphology throughout their lives, can exploit gaps resulting from die-back of the perennials that reach peak biomass in early to mid-July (Whigham et al., 1978; Whigham and Simpson, 1992) or the toppling of annuals, reproduction will occur. In addition, we speculate that competitive stresses associated with small seedling size may account for reliance on a persistent seed bank and this dependence, in turn, is related to small seededness (Thompson and Grime, 1979; Leck, 1989). Of the dominant annuals, Bidens laevis seeds are the lightest and Bidens is the only one to possess a persistent seed bank (Leck and Simpson, 1993)

An interesting feature of this site is the importance (Fig. 2; Table 1) of Cuscuta gronovii, a parasite with a viney habit. In general, low Cuscuta gronovii cover appears to predict a larger seed bank size the following year for Impatiens capensis, its primary host (Figs. 2, 3; Table 6). Also, results (Table 6) suggest that if the host is successful, so is the parasite. We are aware of few reports of parasites in other wetlands. In seed bank samples from eight Iowa prairie marshes, Cuscuta sp. was unimportant (van der Valk and Davis, 1976), but it was frequent in the seed bank (79\%) and vegetation (28\%) of another (van der Valk and Davis, 1978). In addition, note is taken of the occurrence of a hemiparasite (Agalinis paupercula) in the vegetation of an Ontario lake, but no germination occurred from soil samples presumably due to lack of specific nutritional requirements (Keddy and Reznicek, 1982).

The impact of pathogens and parasites on community dynamics is important (e.g., Harper, 1977; May, 1984; Clay, 1990), yet their impact in wetlands has apparently received little attention. Even here, the impact of Cuscuta gronovii on other species, although potentially great (Kuijt, 1969), is not known.

Community ecology assumes, although not unchallenged (e.g., Wiens, 1984; Fowler, 1990), that patterns in natural communities involve competition, and are orderly and predictive. And although we observed a predictable continuance of a suite of annual and perennial species, there were weak (low $r^{2}$ values) interactions among species and lack of correlations among life history stages. It is possible that the disorder, stemming from a variety of sources (Fowler, 1990), decreases the strength of the relationships among species and among life history stages 
TABLE 6. Regression analyses between (A) life history stages, (B) current year cover and seed bank or field seedlings, and (C) previous year cover and life history stages. All significant relationships $(P \leq 0.05)$ are given. Note that all possible combinations of dominant species, and total annuals and perennials were examined.

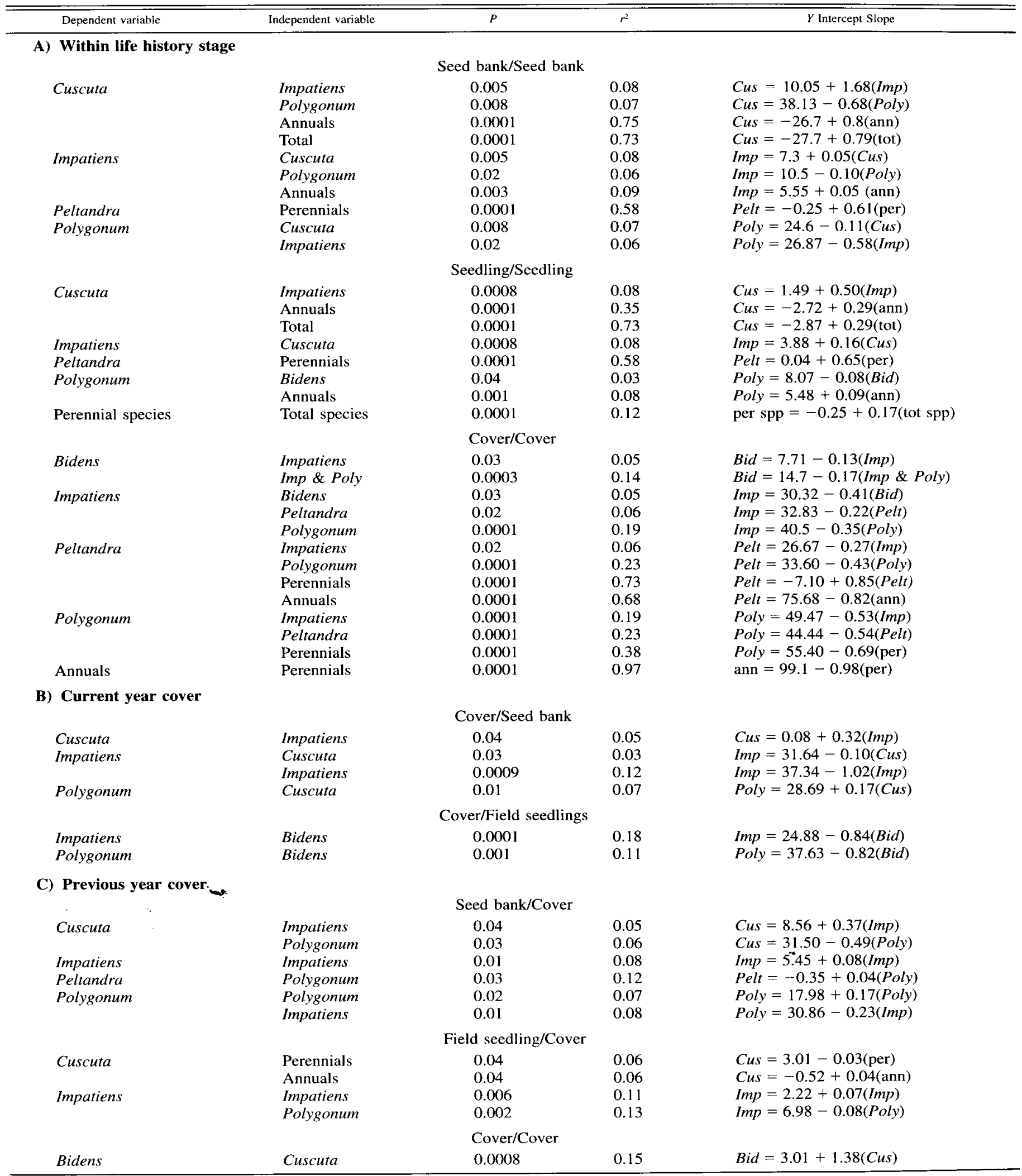


(Table 6). Several other possibilities, with suggestions coming from Strong et al., (1984), exist. (a) Sampling was inadequate to assess species interactions. (b) Competitive patterns do not occur, but other interactions may operate. For example, a species may be a "keystone" species controlling densities of other species, a species may serve as a facilitator in the structuring of the community, or phenological morphological changes (e.g., varying temporal dominance of perennials; Whigham and Simpson, 1992) may reduce overlap in use of resources. (c) Patterns depend on abiotic rather than biotic features, although this seems unlikely given high field seedling densities ( $>4,000$ seedlings $/ \mathrm{m}^{2}$ ). (d) Analyses were unable to discern strong dependent relationships or the causal processes, involving autecology and natural history, that underlie patterns.

This study has shown that annuals vary from year to year, but collectively can be a continuing force in community dynamics. Presumably, because of early germination and high densities, they influence and decrease establishment of perennials. Strategies for each life history stage (seed bank, field seedlings, and vegetation) appear to differ because each species has unique dormancy and/or germination characteristics, seedling tolerances, and growth forms. Over the decade, size and diversity of the three life history stages varied, interactions between species varied, and species variability among the three life history stages varied. Although there were a number of significant relationships (simple linear regression analyses), these were generally weak (low $r^{2}$ values), and, thus, relationships between and among species and between and among life history stages are not strongly dependent (predictable). In addition, germination success did not guarantee establishment. The single reasonable prediction is that, given unchanging hydrology, this high marsh site will continue to be dominated by the same suite of annuals and perennials with year-to-year population fluctuations.

\section{LITERATURE CITED}

Bigwood, D. W., AND D. W. INOUYE. 1988. Spatial pattern analysis of seed banks: an improved method and optimized sampling. Ecology 69: 497-507.

Brock, M. A., K. Theodore, and L. O'Donnell. 1994. Seed bank methods for Australian wetlands. Australian Journal of Marine and Freshwater Research 45: 483-493.

CLAY, K. 1990. The impact of parasitic and mutualistic fungi on competitive interactions among plants. In J. B. Grace and D. Tilman [eds.], Perspectives on plant competition, 391-412. Academic Press, San Diego, CA.

FernaLD, M. L. 1970. Gray's manual of botany. D. van Nostrand, New York, NY.

Forcella, F. 1984. A species area curve for buried viable seeds. Australian Journal of Agricultural Research 35: 645-652.

FowLER, N. L. 1990. Disorderliness in plant communities: comparisons, causes, and consequences. In J. B. Grace and D. Tilman, [eds.], Perspectives on plant competition, 291-306. Academic Press, San Diego, CA.

FrANKLIN, J. F. 1989. Importance and justification of long-term studies in ecology. In G. E. Likens [ed.], Long-term studies in ecology, 319. Springer-Verlag, New York, NY.

Gleason, H. A. 1952. The new Britton and Brown illustrated flora of the northeastern United States and adjacent Canada. Hafner, New York, NY.

- AND A. Cronguist. 1991. Manual of vascular plants of north- eastern United States and adjacent Canada. New York Botanical Garden, Bronx, NY.

GRIME, J. P. 1979. Plant strategies and vegetation processes. John Wiley and Sons, Chichester.

HARPER, J. L. 1977. Population biology of plants. Academic Press, London.

Hopkins, D. R., AND V. T. PARKer. 1984. A study of the seed bank of a salt marsh in northern San Francisco Bay. American Journal of Botany 71: 348-355.

KedDy, P. A., AND A. A. RezniceK. 1982. The role of seed banks in the persistence of Ontario's coastal plain flora. American Journal of Botany 69: 13-22.

KuisT, J. 1969. The biology of parasitic flowering plants. University of California Press, Berkeley, CA.

LECK, M. A. 1989. Wetland seed banks. In M. A. Leck, V. T. Parker, and R. L. Simpson [eds.], Ecology of soil seed banks, 283-305. Academic Press, San Diego, CA.

, C. C. BASkin, AND J. M. BASKin. 1994. Germination ecology of Bidens laevis (Asteraceae) from a tidal freshwater wetland. Bulletin of the Torrey Botanical Club 121: 230-239.

, AND K. J. GRAVELINE. 1979. The seed bank of a freshwater tidal marsh. American Journal of Botany 66: 1006-1015

, AND R. L. SiMPSON. 1987. Seed bank of a freshwater tidal wetland: turnover and relationship to vegetation change. American Journal of Botany 74: $360-370$.

, AND - 1993 . Seeds and seedlings of the Hamilton Marshes, a Delaware River tidal freshwater wetland. Proceedings of the Academy of Natural Sciences of Philadelphia 144: 267-281. , AND - 1994. Tidal freshwater wetland zonation: seed and seedling dynamics. Aquatic Botany 47: 61-75.

- - AND V. T. PARKER. 1989. The seed bank of a freshwater tidal wetland and its relationship to vegetation dynamics. In R. R. Sharitz and J. W. Gibbons [eds.], Freshwater wetlands and wildlife, 189-205. United States Department of Energy, Office of Scientific and Technical Information, Oak Ridge, TN.

MAY, R. M. 1984. An overview: real and apparent patterns in community structure. In D. R. Strong, Jr., D. Simberloff, L. G. Abele, and A. B. Thistle [eds.], Ecological communities: conceptual issues and the evidence, 3-16. Princeton University Press, Princeton, NJ.

MitsCH, W. J., AND J. G. Gosselink. 1986. Wetlands. Van Nostrand Reinhold, New York, NY.

Orson, R. A., R. L. Simpson, And R. E. Good, 1992. The paleoecological development of a late Holocene, tidal freshwater marsh of the Upper Delaware Estuary. Estuaries 15: 130-146.

PARKER, V. T., AND M. A. LECK. 1985. Relationship of seed banks to plant distribution patterns in a freshwater tidal wetland. American Journal of Botany 72: 161-174.

PEDERSON, R. L. 1981. Seed bank characteristics of the Delta Marsh, Manitoba: applications for wetland management. In R. Richardson [ed.], Selected proceedings of the midwest conference on wetland values and management, 61-69. Freshwater Society, Navarre, MN.

SARUKHÁN, J. 1974. Studies on plant demography: Ranunculus repens L., $R$. bulbosa L. and $R$. acris L. II. Reproductive strategies and seed population dynamics. Journal of Ecology 62: 151-177.

SAS. 1989. SAS user's guide: statistics. SAS Institute, Cary, NC.

SCHNEIDER, R. L., AND R. R. Sharitz. 1986. Seed bank dynamics in a southeastern riverine swamp. American Journal of Botany 73: $1022-1030$.

Silander, J. A., JR., And S. W. PaCala. 1990. The application of plant population dynamic models to understanding plant competition. In J. B. Grace and D. Tilman [eds.], Perspectives on plant competition, 67-91. Academic Press, San Diego, CA.

Simpson, R. L., R. E. Good, M. A. Leck, And D. F. Whigham. 1983. The ecology of freshwater tidal wetlands. BioScience 33: 255-259.

Strong, D. R. JR., D. Simberloff, L. G. Abele, and A. B. Thistle, [eds.]. 1984. Ecological communities: conceptual issues and the evidence. Princeton University Press, Princeton, NJ.

Thompson, K., AND J. P. GRIME. 1979. Seasonal variation in the seed banks of herbaceous species in ten contrasting habitats. Journal of Ecology 67: 893-921.

Trlman, D. 1988. Plant strategies and the dynamics and structure of plant communities. Princeton University Press, Princeton, NJ. 
VAN DER Valk, A. G., AND C. B. Davis. 1976. The seed banks of prairie glacial marshes. Canadian Journal of Botany 54: 1832-1838.

, AND —. 1978. The role of seed banks in the vegetation dynamics of prairie glacial marshes. Ecology 59: 322-335.

WIENS, J. A. 1984. On understanding a non-equilibrium world: myth and reality in community patterns and processes. In D. R. Strong, Jr., D. Simberloff, L. G. Abele, and A. B. Thistle [eds.], Ecological communities: conceptual issues and the evidence, 3-16. Princeton University Press, Princeton, NJ.
Whigham, D. F., J. MCCormick, R. E. Good, ANd R. L. Simpson. 1978. Biomass and primary production in freshwater tidal wetlands of the Middle Atlantic Coast. In R. E. Good, D. F. Whigham, and R. L. Simpson [eds.], Freshwater wetlands: ecological processes and management potential, 3-20. Academic Press, New York, NY.

, AND R. L. SIMPSON. 1992. Annual variation in biomass and production of a tidal freshwater wetland and comparison with other wetland systems. Virginia Journal of Science 43: 5-14.

ZAR, J. H. 1979. Biostatistical analysis. Prentice Hall, Englewood Cliffs, NJ

APPENDIX 1. Species recorded in seed bank samples (b), as field seedlings (f), and in the vegetation (cover quadrats, c). For 1985 only seed bank data are available.

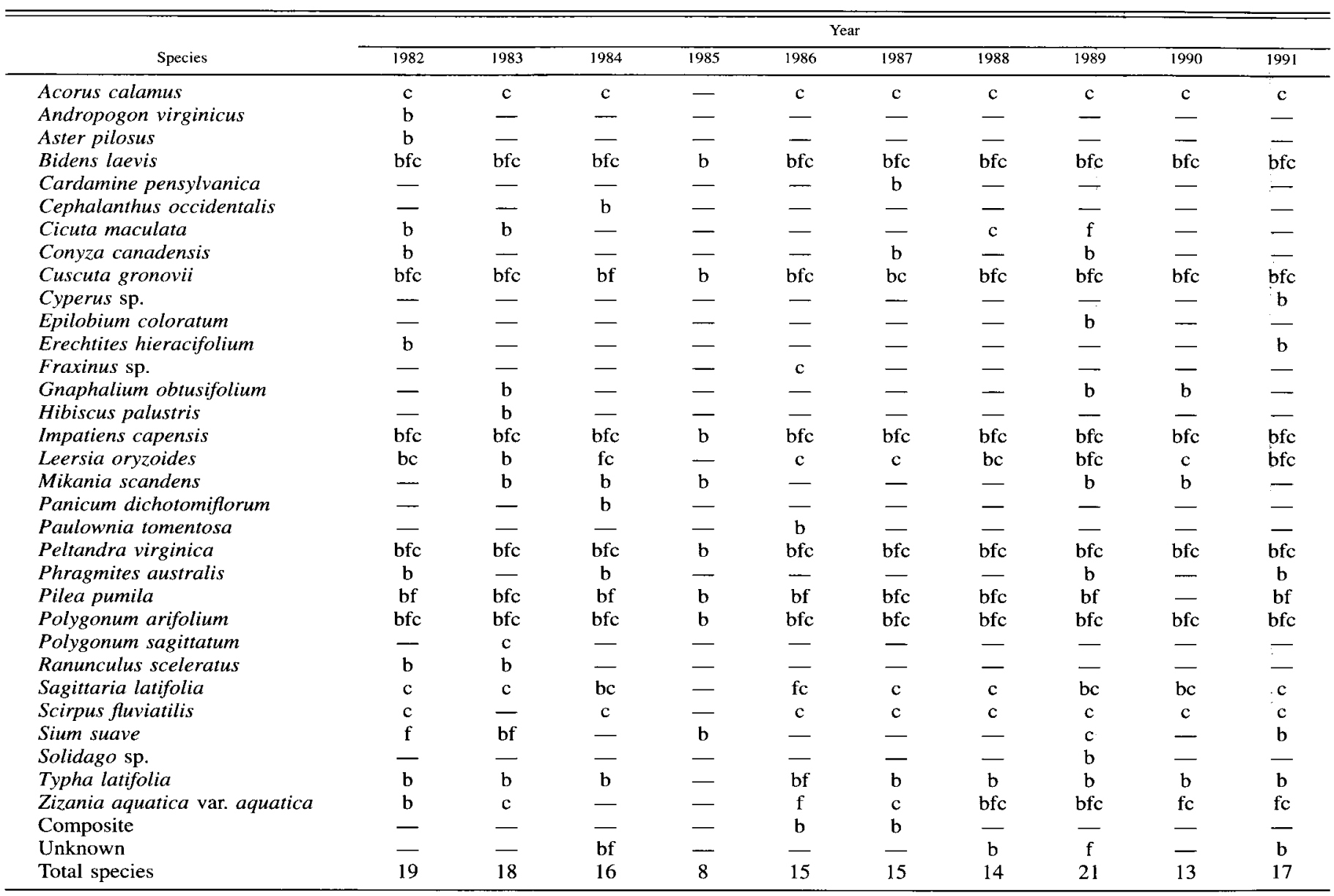

